\title{
Synergism and Antagonism among Indigenous Hydrolytic Bacteria from Biomedical Wastes for the Generation of Bacterial Consortium Used as Bioremediation Agent
}

\author{
Stalis Norma Ethica, Rifki Muslim, RM Bagus Irawan Widyawardhana, Akbar Firmansyah, Sakti Imam \\ Muchlissin, and Sri Darmawati
}

\begin{abstract}
The key steps to develop bioremediation agent from indigenous group of hydrolytic bacteria include isolation of the bacteria from polluted site followed by evaluation on pathogenicity levels and interactions among the isolated strains. This study aimed to evaluate synergism and antagonism between non-pathogenic and pathogenic groups of hydrolytic bacteria isolated from liquid biomedical wastes of hospitals in Semarang. Interactions among indigenous, non-pathogenic, hydrolytic bacterial isolates i.e. Bacillus velezensis $\mathrm{R} 1.3, \mathrm{~B}$. amyloliquefaciens R1.6, $B$. amyloliquefaciens R1.14, B. velezensis R1.16, $B$. licheniformis $\mathbf{R 2 . 5 ,}$ and $B$. amyloliquefaciens $\mathbf{R 2 . 9}$ and with 20 other pathogenic ones were evaluated using overlay and cross streak methods. Observation was based on the formation of inhibition zone as evidence of antagonistic interaction and the absence of this zone as proof of synergic interaction. As results, the 6 non-pathogenic isolates are all synergic among each other, yet antagonistic against most of the 20 pathogenic ones. As conclusion, the obtained 6 non-pathogenic isolates could be mixed as bacterial consortium and used as major component of bioremediation agent of liquid hospital waste.
\end{abstract}

Index Terms-Bioremediation agent, biomedical waste, hydrolytic bacteria, Semarang hospital.

\section{INTRODUCTION}

Potential of non-pathogenic, indigenous, hydrolytic bacteria to be used as bioremediation agent has been recognized. Hydrolytic bacteria have been known for their ability in reducing water pollution parameter values of organic matters, the main ingredient of biomedical waste

Manuscript received on April 29, 2019; revised September 12, 2019. This work was supported in part by the Kemenristek Dikti or Indonesian Ministry of Research and Higher Education, through Program Penelitian Terapan (PPT) under Grant 0608/IINIMUS.LIST.PT/2019.

Stalis Norma Ethica and Sri Darmawati were with the Medical Laboratory Technology Study Program, Faculty of Nursing and Health Sciences, Universitas Muhammadiyah Semarang, 50273, Indonesia. They are now with the Magister Program of Medical Laboratory Science, Universitas Muhammadiyah Semarang, 50273, Indonesia (e-mail: norma@unimus.ac.id, ciciekdarma@unimus.ac.id).

Rifki Muslim was with Medical Faculty, Universitas Muhammadiyah Semarang, 50273, Indonesia (e-mail: rs_roemani@yahoo.co.id).

RM Bagus Irawan Widyawardhana was with Mechanical Engineering Study program, Faculty of Engineering, Universitas Muhamamdiyah Semarang, 50273, Indonesia (e-mail: bagus@unimus.ac.id)

Akbar Firmansyah was with Faculty of Marine Science and Fisheries, Universitas Diponegoro, Semarang, 50275, Indonesia (e-mail: akbarfirmansh@gmail.com).

Sakti Imam Muchlissin was with Magister of Marine Sciences Study Program, Universitas Diponegoro, Semarang, 50275, Indonesia (e-mail muchlissin@outlook.com).
[1]-[3]. The bacterial hydrolytic enzyme is the main degrader of organic pollutants because it is able to break down the main chemical bonds of toxic organic molecules in waste [4], [5], thus it is important for biomedical waste bioremediation.

The ability of hydrolytic bacteria used as bioremediation agent of biomedical waste depends not only on the ability of the enzyme they produced to degrade waste materials, but also the ability of the bacteria to inhibit the growth of non-pathogenic hydrolytic bacteria. It is therefore important to ensure that the selected bacteria used as components of bioremediation agent could work together in degradation process as consortium, while on the other hand show inhibition interactions with the pathogenic ones [1]-[3, [6].

Previous studies have underlined that the ability of bacterial consortium to degrade pollutants is more significant as compared to that of individual isolates. Therefore, it is important to prepare bacterial consortium from individual isolates in degradation studies [7], [8]. To achieve synergic work in degradation by bacterial consortium, it is necessary to make sure that individual isolates as its components do not show antagonist interaction among others. Thus, it is essential to evaluate both synergism and antagonism among non-pathogenic bacterial isolates before mixing them as components of consortium.

Cross streak technique has been known as a rapid way to screen microorganisms for antagonism [9]. According to this technique, microbial strain of interest is cultivated on agar plate by single streaking. After incubated, the plate is cultivated with the microorganisms tested on the same plate by another single streaking perpendicular to the previous streak. After further incubation, the interactions are evaluated by observing inhibition zone size Balouiri et al., [10] The presence of inhibition zone is an evidence of antagonism, while the absence of this zone is indication of synergism. Aside of cross streak method, agar overlay bioassay or double layer agar test could also be used for screening of microorganisms showing antagonism interactions. This method contains 2-steps of media preparation, including the solid and soft top agar [11], [12].

This study aimed to evaluate both synergism and antagonism among pathogenic and non-pathogenic group of indigenous, hydrolytic bacterial isolates. Such evaluation is used to determine potential of these bacteria to be mixed as consortium functioning as bioremediation agent of biomedical waste. 


\section{MATERIALS AND METHOD}

\section{A. Bacterial Strains}

The bacteria used in this study were recovered from Indonesian B- and C- class hospitals, (Roemani Muhammadiyah Hospital, R1) and (RSUD KRT (Rumah Sakit Umum Daerah Kanjeng Raden Tumenggung) Wongsonegoro Hospital, R2) located in Semarang, Central Java, Indonesia. As many as 26 isolates of indigenous hydrolytic bacteria were obtained during isolation [6], [13]. Based on MacConkey and BAP analysis, 6 of these isolates were known as non-pathogenic, while the rest were considered as pathogenic.

\section{B. Media, Reagents and Equipment}

The media and reagents used in this study were nutrient agar (NA), nutrient broth (NB), all from (Merck Germany), $\mathrm{NaCl}$. ethanol 70\%, and aquadest. Equipment used in the experiment were reaction tubes, bunsen, bacterial plates, micropipette tips, laminar flow, bunsen, cuvette, autoclave, and spectrophotometer.

\section{Cross Streak Method for Synergism Evaluation}

The synergical activity among 6 non-pathogenic isolates was evaluated by Cross Streak method [9], [14]. Each of the 6 isolates was streaked on NA medium as straight line and incubated at $30^{\circ} \mathrm{C}$ for six days. Then the plates were seeded with similar other ( 6 isolates) by a single streak at a $90^{\circ}$ angle to the previous streaked isolates and incubated at $37^{\circ} \mathrm{C}$ for 24 $\mathrm{h}$. The synergical interactions among tested isolates were analyzed by the absence of inhibition (clear) zone around the crosses between streaked lines of colonies.

\section{Overlay Method for Antagonism Evaluation}

Every loopful of pathogenic strain from 20 colonies obtained from previous study [6] was planted on solid NA media using micropipette tips. Every plate contained 5 different colonies, therefore 4 plates were required. This step was repeated 6 times as there were 6 non-pathogenic strains to be tested, resulting 24 plates with grown strains. All of these plates were incubated at $37^{\circ} \mathrm{C}$ for 2 days. Meanwhile, the concentration of every of 6 non-pathogenic strain cultures was adjusted to $0,5 \mathrm{McFarland}$ standards. A mL of every non-pathogenic isolate in NB media was taken and inserted separately into $100 \mathrm{~mL}$ soft agar. Soft top agar medium was prepared in reaction tube containing $70 \%$ concentration of agar, which previously had been boiled at $100^{\circ} \mathrm{C}$ and then cooled to $45^{\circ} \mathrm{C}$. Next, the top soft agar containing non-pathogenic test bacteria was immediately poured into each solid medium that has been overgrown with the isolates of pathogenic bacteria, then incubated at $37^{\circ} \mathrm{C}$ for $24 \mathrm{~h}$ to allow all media to solidify [11], [12]. All of these steps were illustrated in Fig. 1.

After 24-h incubation, observation was carried out on the overlaid cultures. If there is reduction in the turbidity of the lawn around the colony (plaque) of bacteria of interest, then it means that inhibition of bacterial growth occurs [12].

\section{E. Data Analysis}

The formation of transparent zones as evidence of inhibition of bacterial growth using both cross-streak and overlay methods was checked. Qualitative data were collected and summarized in tables.

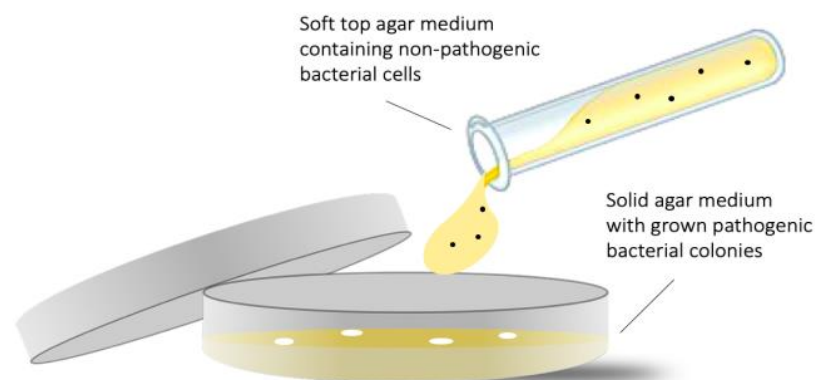

Fig. 1. Illustration of overlay technique used in this study.

\section{RESUltS AND DisCUSSION}

In vitro cross-antagonistic tests were carried out on 6 non-pathogenic isolates used in this study. It aimes to observe possible antagonism interactions among these non-patogen hydrolytic bacterial isolates. The cross-streak procedure followed was first reported by Burkholder et al. [15]. The results were summarized in Table I.

TABLE I: MATRIX USED IN SYNERGISM ANALYSIS

\begin{tabular}{lcccccc}
\hline & \multicolumn{6}{c}{ Non-pathogenic strains } \\
\cline { 2 - 7 } Non-pathogenic strains & $\mathrm{R} 1.3$ & $\mathrm{R} 1.6$ & $\mathrm{R} 1.14$ & $\mathrm{R} 1.16$ & $\mathrm{R} 2.5$ & $\mathrm{R} 2.9$ \\
\hline \hline R1.3 & $\mathrm{X}$ & & & & & \\
R1.6 & $\mathrm{V}$ & $\mathrm{X}$ & & & & \\
R1.14 & $\mathrm{V}$ & $\mathrm{V}$ & $\mathrm{X}$ & & & \\
R1.16 & $\mathrm{V}$ & $\mathrm{V}$ & $\mathrm{V}$ & $\mathrm{X}$ & & \\
R2.5 & $\mathrm{V}$ & $\mathrm{V}$ & $\mathrm{V}$ & $\mathrm{V}$ & $\mathrm{X}$ & \\
R2.9 & $\mathrm{V}$ & $\mathrm{V}$ & $\mathrm{V}$ & $\mathrm{V}$ & $\mathrm{V}$ & $\mathrm{X}$ \\
\hline \hline
\end{tabular}

Note: $\mathrm{v}=$ Synergism among isolates sinergis; $\mathrm{X}=$ Between similar isolates were not tested.

The cross-streaked colonies were examined every day to determine the presence of inhibitory zones that were at least 4 $\mathrm{mm}$ larger than the diameter of bacterial colonies planted on both sides as evidence of antagonistic interactions [16]. In this study, inhibitory zones were not observed (Fig. 2.) indicating that all non-pathogenic isolates are synergic interacted.

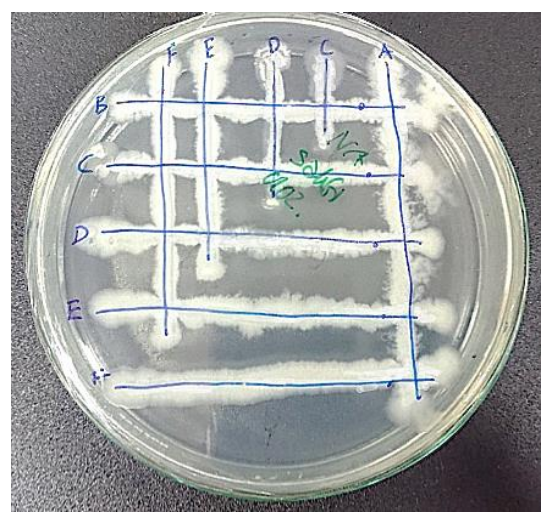

Fig. 2. The results of the observation of the synergistic test between the selected nonpathogenic hydrolytic bacteria. Note: The test is done in duplicate. Note: A = Isolate R1.3; B = Isolate R1.6; C = Isolate R1.14; D = Isolate R1.16; E = Isolate R2.5; and F = Isolate R3.9

The synergic interaction between these isolates implies 
that the 6 isolates have the potential to be made a consortium in waste degradation process.

In this study, overlay method was used to determine antagonism among non-pathogenic and pathogenic isolates. Results of the overlay tests to determine antagonism among all hydrolytic bacteria tested is displayed in Fig. 2 .
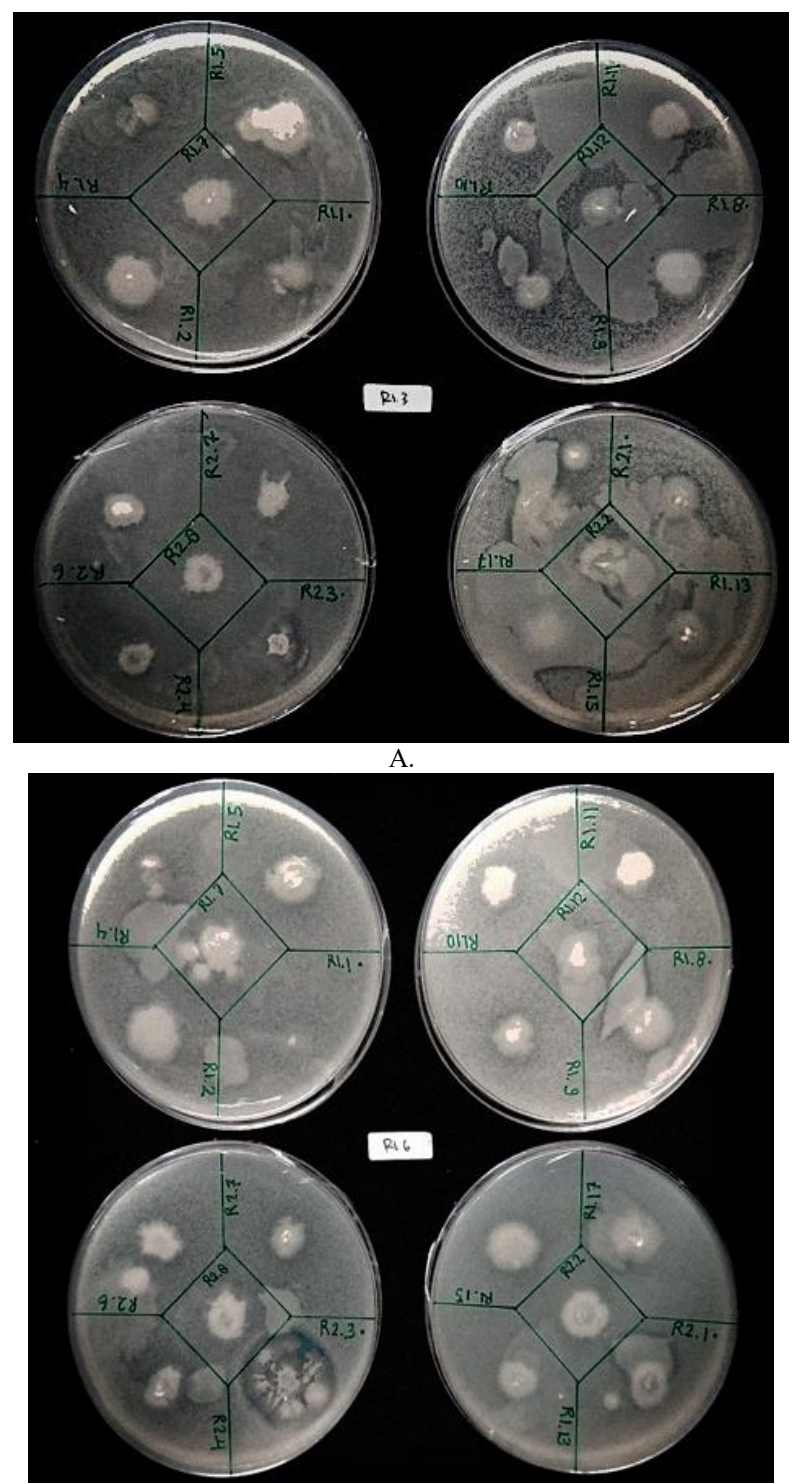

B.

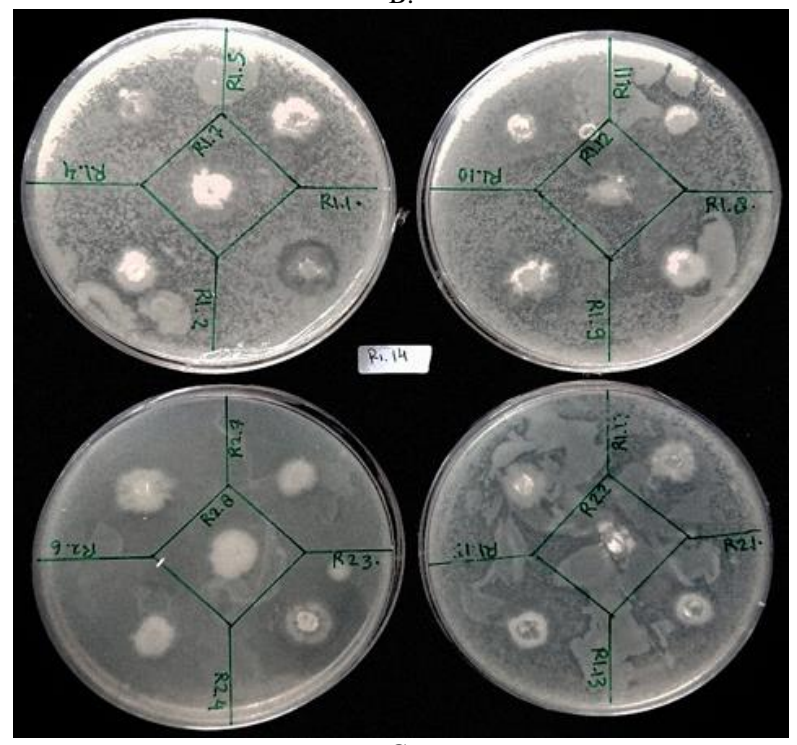

C.

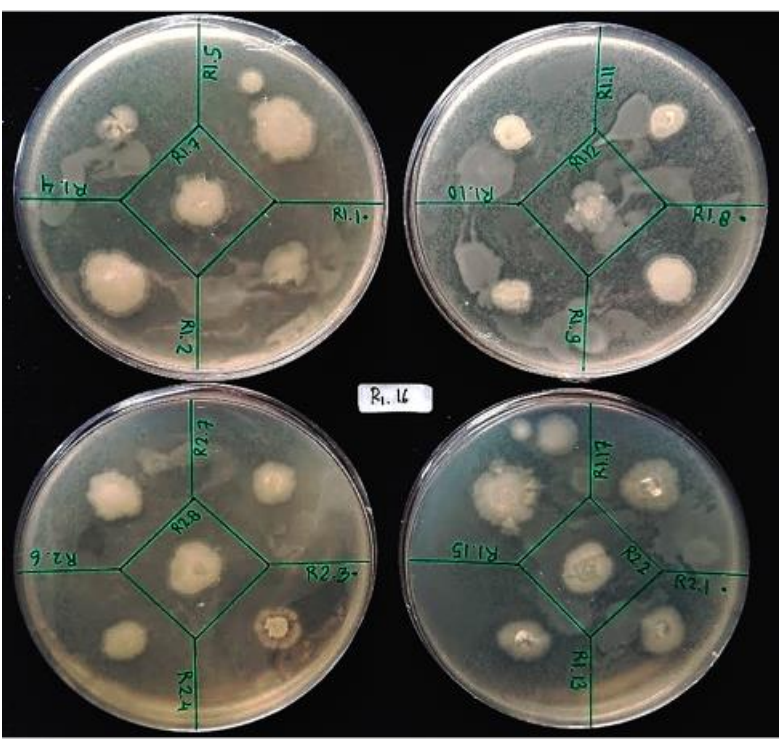

D.
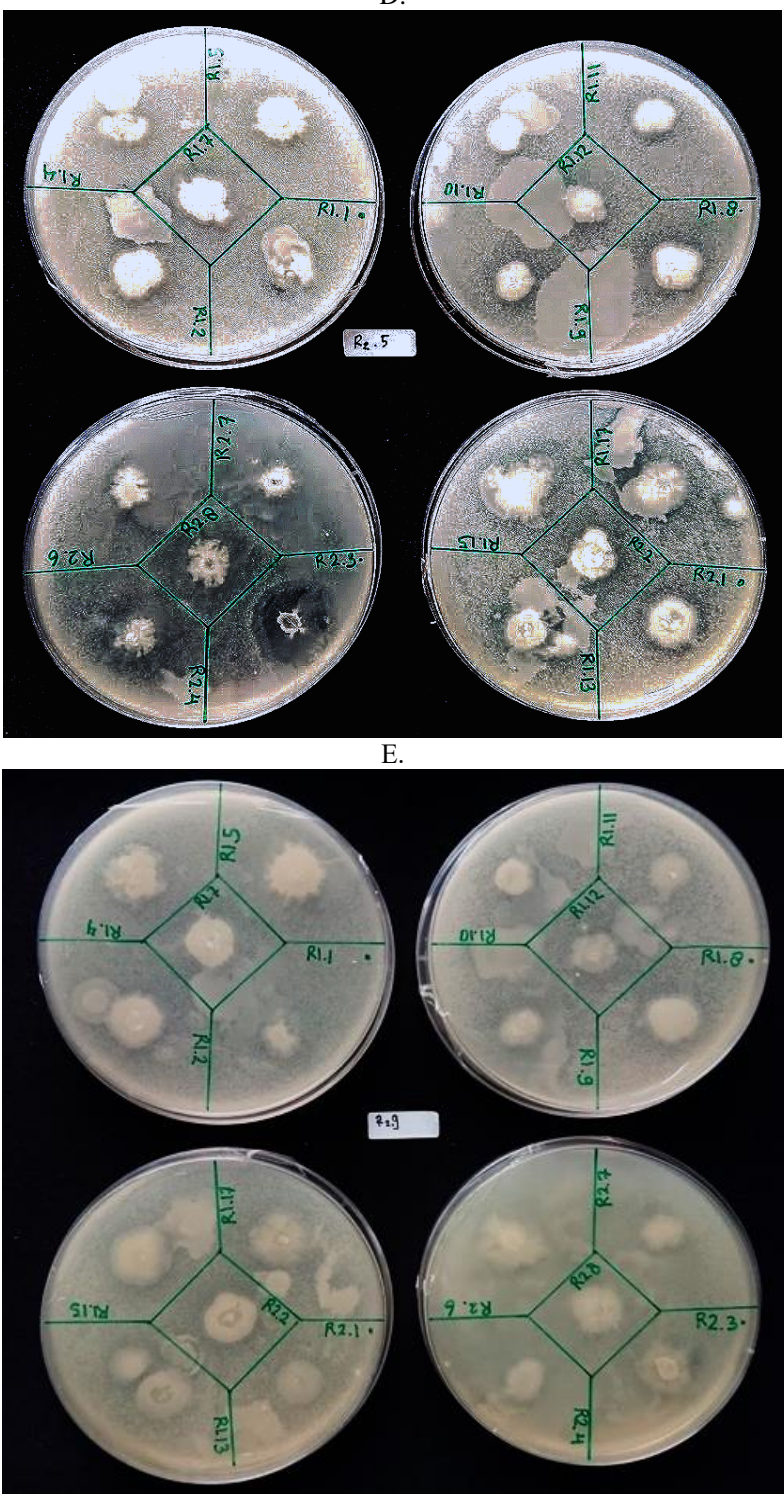

F.

Fig. 3. The results of the observation of the synergistic test between the selected nonpathogenic hydrolytic bacteria. Note: The test is done in duplicate. Note: A = Isolate R1.3; B = Isolate R1.6; C = Isolate R1.14; D = Isolate R1.16; E = Isolate R2.5; and F = Isolate R3.9.

Antagonism test was conducted to see the ability of 6 non-pathogenic hydrolytic bacterial isolates to interact antagonistically with 20 pathogenic ones from similar source 
(hospital biomedical waste). The antagonistic properties of pathogenic bacteria contained in biomedical wastes are important characteristics that bacterial isolates need to be used as bioremediation agents for liquid biomedical waste. Besides being expected to be able to improve the value of liquid waste pollution parameters, bioremediation agents should also be able to reduce waste toxicity due to the activity of pathogenic bacteria in waste.

Evidence of antagonism between a non-pathogenic isolate to interact antagonistically with the pathogenic one is indicated by the presence of a clear zone of inhibition around the pathogenic colony on solid media after contact with nonpathogenic bacteria cells from soft top layer. The antagonistic test results are shown in Table II.

TABLE II: SUMMARY OF ANTAGONISM TEST RESULTS AMONG PATHOGENIC AND NON-PATHOGENIC STRAINS

\begin{tabular}{lcccccc}
\multicolumn{7}{c}{ AND NON-PATHOGENIC STRAINS } \\
Pathogenic & \multicolumn{7}{c}{ Non-pathogenic strains } \\
\cline { 2 - 7 } strains & $\mathrm{R} 1.3$ & $\mathrm{R} 1.6$ & $\mathrm{R} 1.14$ & $\mathrm{R} 1.16$ & $\mathrm{R} 2.5$ & $\mathrm{R} 2.9$ \\
\hline \hline R1.1 & + & - & + & + & + & + \\
R1.2 & + & + & + & + & + & + \\
R1.4 & + & + & + & + & + & + \\
R1.5 & + & + & + & + & + & + \\
R1.7 & + & + & + & + & + & + \\
R1.8 & + & + & + & + & + & - \\
R1.9 & + & + & + & + & + & + \\
R1.10 & - & + & + & - & + & + \\
R1.11 & + & + & + & + & + & + \\
R1.12 & - & + & + & + & + & + \\
R1.13 & + & + & + & + & + & + \\
R1.15 & + & + & + & + & + & + \\
R1.17 & + & + & + & + & + & + \\
R2.1 & + & + & + & + & + & + \\
R2.2 & + & + & + & + & + & + \\
R2.3 & + & + & + & + & + & + \\
R2.4 & + & + & + & + & - & + \\
R2.6 & + & + & + & + & + & + \\
R2.7 & + & + & + & + & + & + \\
R2.8 & + & + & - & + & + & - \\
\hline
\end{tabular}

Note: " + " presence of antagonism (formation of inhibition zone); "-" absence of antagonism.

Based on results shown in Table II, generally all non-bacterial strains tested in this study (R1.3; R1.6; R1.14; $\mathrm{R} 1.16$; R2.5; and R2.9) showed antagonistic interactions with the pathogenic ones with only few exceptions. Only 8 of 120 possible interactions that could not visibly confirmed as antagonism. For example, non-pathogenic strain R1.3 could not show antagonism only with R1.10 and R1.12 pathogenic strains. Non-pathogenic strain R1.6, R1.14, R1.16, R2.5 could not show antagonism against pathogenic strains R1.1, R2.8, R1.10, and R2.4, respectively. Next, non-pathogenic strain R2.9 failed to establish inhibition zone with two pathogenic strains, R1.8 and R2.8. However, since the observation was made after 24 -h contact between pathogenic and non-pathogenic groups, there is still possibility that the inhibition could be more visible after longer (more than 24-h) contact time.

Microbial interactions, which could be cooperative or interfering, often defined as synergism or antagonism relationships, have long been recognized as important determinants in ecology. Common interference mechanisms include the competition for adhesion sites and nutrients, also the production of specific antimicrobial compounds or toxic metabolites and [11]. Results in this study confirmed that cross streak method could provide good result in screening antagonistic activity of tested bacteria as previously reported by Lertcanawanichakul \& Sawangnop). Based on analysis using cross-streak method, the tested indigenous bacteria from hospital wastes, which could produce degrading enzymes, Bacillus velezensis R1.3, B. amyloliquefaciens R1.6, B. amyloliquefaciens R1.14, B. velezensis R1.16, B. licheniformis R2.5, and B. amyloliquefaciens R2.9 could demonstrate no inhibition among each other. This shows their potential to be mixed as consortium in bioremediation process of biomedical waste.

Parts of results using overlay method (see Fig. 2), though interpretable, meets the description of grainy appearance reported by Hockett \& Baltrus [12]. Interpretation, however, is dependent on the strength of the inhibition, where weaker inhibition might be harder to observe. As seen in Fig. 2, several non-pathogenic isolates could not produce clear zone of inhibition against a number of pathogenic. Yet, there is possibility that in this case inhibitions actually occurred, but too weak to be observed.

Above all, both cross-streak and overlay methods are found to be useful for bioremediation study, particularly in determining components of hydrolytic bacterial consortium used as bioremediation agent. When used as bioremediation agent, the determined consortium should be able not only to degrade main organic matters as main of component biomedical waste, but also to compete with pathogenic bacteria found in such waste.

\section{CONCLUSION}

Based on results reported in this study, it could be concluded that:

1) The six non-pathogenic strains of indigenous, hydrolytic bacteria: Bacillus velezensis R1.3, B. amyloliquefaciens R1.6, B. amyloliquefaciens R1.14, B. velezensis R1.16, B. licheniformis R2.5, and B. amyloliquefaciens R2.9 are synergic interacted with each other, so they could be mixed as consortium in waste degradation process.

2) The six non-pathogenic strains of indigenous, hydrolytic bacteria tested in this study could establish antagonism with most of 20 pathogenic indigenous, hydrolytic ones making them potential to be used as bioremediation agent by suppressing growth of pathogenic bacteria in wastes.

For future work, the performance of the determined bacterial consortium as components of bioremediation agent should be tested in improving wastewater pollution parameters such as TSS (total suspended solids), BOD (biological oxygen demand), phosphate, ammonia, etc.

\section{CONFLICT OF INTEREST}

The authors declare no conflict of interest.

\section{AUTHOR CONTRIBUTION}

SNE, RM and RMBIW planned the experiments. AF and SIM conducted the laboratory experiments including sample 
preparation. SNE and SD contributed to the interpretation of the results. SNE led the preparation and the submission of the manuscript. SD provided critical feedback on the research, analysis and paper writing. All authors had approved the final version.

\section{ACKNOWLEDGMENT}

All authors would like to thank Roemani Muhammadiyah and RSUD KRT Wongsonegoro Hospitals for providing sampling locations of this study. S.N.E. expresses special gratitude to the Director of Roemani Hospital, Prof. Dr. dr. H. Rifki Muslim Sp.B, Sp.U. as corporate partner in this research. Authors greatly thank to Prof. Dr. Agus Sabdono, M.Sc. from Universitas Diponegoro for his great advice for the completion of this research.

\section{REFERENCES}

[1] E. S. Norma et al., "The development method of bioremediation of hospital biomedical waste using hydrolytic bacteria," Health and Technology, vol. 8, no. 4, pp. 239-254, Sep. 2018.

[2] E. S. Norma and A. Sabdono, "Bio-remediation potential of hydrolytic bacteria isolated from hospital liquid biomedical waste in Central Java," in Proc. the 3rd World Congress on New Technologies, pp. 1-2, 2017.

[3] E. S. Norma et al., "Sampling mikrobiologi limbah biomedis rumah sakit di kota semarang jawa tengah," Prosiding Seminar Nasional \& Internasional, vol. 1, no. 1, 2017.

[4] S. Babita, A. K. Dangi, and P. Shukla, "Contemporary enzyme based technologies for bioremediation: A review," Journal of Environmental Management, vol. 210, pp. 10-22, 2018

[5] K. S. Chandrakant and S. S. Rao, "Role of microbial enzymes in the bioremediation of pollutants: A review," Enzyme Research, 2011.

[6] E. S. Norma et al., "Protease producers predominate cultivable hydrolytic bacteria isolated from liquid biomedical waste," Asian Journal of Chemistry, vol. 30, no. 9, pp. 2035-2038, July 2018.

[7] S. Santina et al., "Biodegradation of crude oil by individual bacterial strains and a mixed bacterial consortium," Brazilian Journal of Microbiology, vol. 46, no. 2, pp. 377-387, June 2015.

[8] D. Monika, A. Kumar, and A. Juwarkar, "Petroleum contaminated oil sludge degradation by defined consortium: Influence of biosurfactant production," in Proc, the National Academy of Sciences, India Section B: Biological Sciences, vol. 88, no. 2, pp. 517-523, June 2018.

[9] L. Monthon and S. Sawangnop, "A comparison of two methods used for measuring the antagonistic activity of Bacillus species," Walailak Journal of Science and Technology, vol. 5, no. 2, pp. 161-171, 2011.
[10] B. Mounyr, M. Sadiki, and S. K. Ibnsouda, "Methods for in vitro evaluating antimicrobial activity: A review," Journal of Pharmaceutical Analysis, vol. 6, no. 2, pp. 71-79, 2016.

[11] M. J. Gil et al., "Synergistic growth effect among bacteria recovered from root canal infections," Brazilian Journal of Microbiology, vol. 42, no. 3, pp. 973-979, Sep. 2011.

[12] H. L. Kevin and D. A. Baltrus, "Use of the soft-agar overlay technique to screen for bacterially produced inhibitory compounds," JoVE (Journal of Visualized Experiments), vol. 119, 2017, p. e55064.

[13] S. Agus and E. S. Norma, "Biodiversity of hydrolytic bacteria isolated from hospital liquid biomedical waste in Central Java, Indonesia," Book of Abstracts - 4th International Congress on Environmental Research and Technology, p. 2, Nov. 2018

[14] H. Nazmul and M. Rahman, "Antagonistic activity of antibiotic producing Streptomyces sp. against fish and human pathogenic bacteria," Brazilian Archives of Biology and Technology, vol. 57, no. 2, pp. 233-237, Apr. 2014

[15] B. R. Paul, R. M. Pfister, and F. H. Leitz, "Production of a pyrrole antibiotic by a marine bacterium," Appl. Environ. Microbiol., vol. 14, no. 4, pp. 649-653, 1966

[16] H.-P. Grossart et al., "Antagonistic activity of bacteria isolated from organic aggregates of the German Wadden Sea," FEMS Microbiology Ecology, vol. 47, no. 3, pp. 387-396, March 2004

Copyright $\odot 2019$ by the authors. This is an open access article distributed under the Creative Commons Attribution License which permits unrestricted use, distribution, and reproduction in any medium, provided the original work is properly cited (CC BY 4.0).

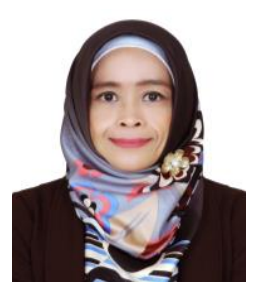

Stalis Norma Ethica earned her bachelor and master degrees from Chemistry Department, Gadjah Mada University, Indonesia. She obtained the doctorate in biotechnology from the same university majoring microbial biotechnology in 2014. She pursued advanced course in bioinformatics sponsored by Wellcome Genome Campus (EMBL-EBI) Cambridge, UK in 2018. She used to work in various industries in Indonesia, China and Australia. She is now a full-time lecturer in Magister Program of Medical Laboratory Science, Universitas Muhammadiyah Semarang, Central Java, Indonesia.

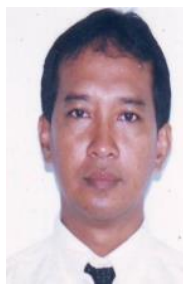

Agus Sabdono graduated from Satya Wacana Cristian University, and got the master from University of Kentucky, USA in 1989. He obtained his doctorate degree from Gadjah Mada University, Indonesia in 2001. His major fields of research are marine sciences and bioremediation. His interest is in marine microbiology and biotechnology, also coral reef biodiversity and conservation. $\mathrm{He}$ is now a full-professor in Marine Science Department, Universitas Diponegoro, Semarang, Central Java, Indonesia. 